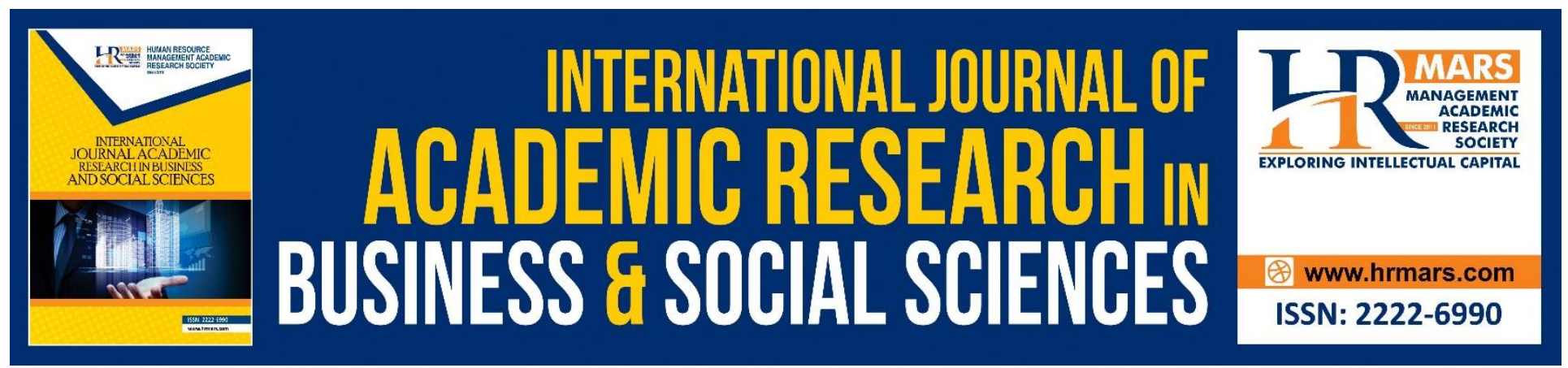

\title{
Application of ICT in Teaching and Learning (TL) Malay Literature to Generate Students' Creativity
}

Mohd Amir Mohd Zahari, Rohizani Yaakub, Azrul Azizi Amirrul Norazimah Zakaria

To Link this Article: http://dx.doi.org/10.6007/IJARBSS/v10-i11/7533 DOI:10.6007/IJARBSS/v10-i11/7533

Received: 20 September 2020, Revised: 19 October 2020, Accepted: 10 November 2020

Published Online: 30 November 2020

In-Text Citation: (Zahari, Yaakub, \& Zakaria, 2020)

To Cite this Article: Zahari, M. A. M., Yaakub, R., \& Zakaria, A. A. A. N. (2020). Application of ICT in Teaching and Learning (TL) Malay Literature to Generate Students' Creativity. International Journal of Academic Research in Business and Social Sciences. 10(11), 156-173.

Copyright: (C) 2020 The Author(s)

Published by Human Resource Management Academic Research Society (www.hrmars.com)

This article is published under the Creative Commons Attribution (CC BY 4.0) license. Anyone may reproduce, distribute, translate and create derivative works of this article (for both commercial and non-commercial purposes), subject to full attribution to the original publication and authors. The full terms of this license may be seen

at: http://creativecommons.org/licences/by/4.0/legalcode

Vol. 10, No. 11, 2020, Pg. 156 - 173

http://hrmars.com/index.php/pages/detail/IJARBSS

JOURNAL HOMEPAGE

Full Terms \& Conditions of access and use can be found at http://hrmars.com/index.php/pages/detail/publication-ethics 


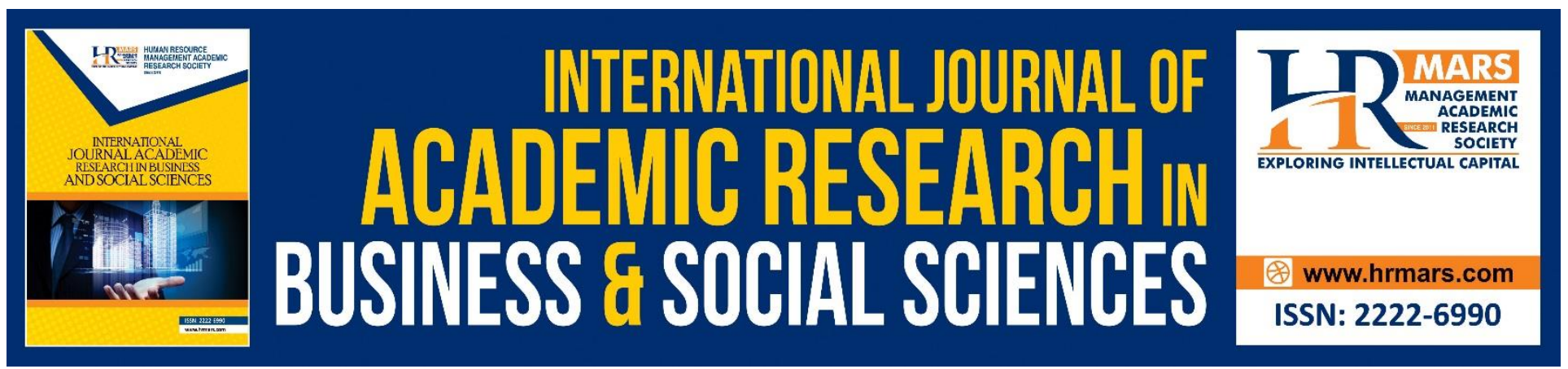

\title{
Application of ICT in Teaching and Learning (TL) Malay Literature to Generate Students' Creativity
}

\author{
Mohd Amir Mohd Zahari, Rohizani Yaakub, Azrul Azizi Amirrul \\ Norazimah Zakaria
}

Department of Malay Language And Literature, Universiti Pendidikan Sultan idris, School of Education Studies, Universiti Sains Malaysia

Email: amir.mz@fbk.upsiedu.my

\begin{abstract}
The use of ICT in TL sessions have a great impact on students as well as teachers in generating creative thinking. It encourages Malay Literature teachers to carry out the process of TL attractively and effectively. It can also contribute to make the process of TL more practical and engage Malay Literature students to maximize their creativity skills. Thus, using ICT technology enables teachers to prepare ahead of time for TL sessions, as teachers can find the necessary information about the teaching they want to convey so that it is faster and more accurate. The findings showed that $100 \%$ of students are interested in studying Malay Literature subject and the methods of teaching literature are good, they like teachers who teach these subjects and presume Malay Literature subject to develop a positive attitude. This study also found that $78 \%$ of teachers use ICT in the classroom. $40 \%$ also say that they have difficulties to learn Malay Literature subject while $60 \%$ do not. This study was conducted qualitatively, using text analysis, library research and field studies to complete a study based on 58 Malay respondents composed of $26 \%$ female students and $74 \%$ male students. The use of ICT in TL of Malay Literature can help to improve creative thinking of Malay Literature students.
\end{abstract}

Keywords: Application of ICT, Teaching and Learning, Malay Literature, Creative Thinking, Creativity, Students' Skill

\section{Introduction}

ICT (Information and Communication Technology) can give a positive impact on a major change in the field of education, especially when it comes to the aspect of TL (Rogayah \& Aderi, 2016). It proves that the use of ICT can help educators to conduct TL sessions more efficiently, practically and also able to attract students and at the same time it can maximize the effectiveness of learning outcomes more creatively (Shah, Mohd, Khadijah \& Abdul, 2017). Now, in the era of globalization, development and rapidity of ICT are demanding in school system especially to implement a paradigm shift and also to remain relevant in terms of preparation and development of human capital for the country to achieve developed country status (Christina \& Hazman, 2009; Marlina et al. 2016). Ironically, according to a statement from Ministry of Education Malaysia (MOE), it states that importance of ICT 
INTERNATIONAL JOURNAL OF ACADEMIC RESEARCH IN BUSINESS AND SOCIAL SCIENCES Vol. 10, No. 11, 2020, E-ISSN: 2222-6990 @ 2020 HRMARS

is being outlined in the 7th shift on Malaysia Education Blueprint 2013-2025 (PPPM 2013-2025) (MOE 2013) which mentions that to "leverage ICT to scale up quality learning across Malaysia". In addition, according to Department of Higher Education Malaysia (DHEM), they also outlined a statement that "global online learning" in the 8th shift (Malaysia Higher Education Blueprint 2013-2025) is one of the efforts in using ICT to enhance the standard of education, especially in generating students' creative thinking in every school.

To generate students' creative thinking is one of the most important elements in the education system in our country (Norfarhana, 2012). In this regard, a study needs to be conducted to study aspects of ICT applications in TL of Malay Literature in generating creative thinking among Malay Literature students. Teachers play an important role by improving skills in mastering the use of ICT especially during TL sessions in the classroom. The use of ICT in TL sessions can have a good effect on students and teachers (Noorhadi \& Zurinah, 2017). This technology allows teachers to prepare in advance in conducting TL sessions since teachers can find any necessary information needed regarding the teaching process to be delivered more promptly and systematically (Joseph \& Wan 2013).

\section{Problem Statement}

In discussing pedagogical aspects about TL of Malay Literature, there are numerous ways, methods and teaching techniques that can be used by teachers in school nowadays. The main focus of methods in TL of Malay Literature is emphasising on ideas and themes as well as the ability of students to be independent without relying entirely on their teachers. It mentions that the success or failure of TL sessions depends on teachers who delivered the lessons (Sharifah \& Kamarul, 2011). In this case, teachers should not only have knowledge that is quite effective in the content of teaching to be delivered, but teachers also need to know knowledge about psychology, sociology and most importantly pedagogical knowledge (Joseph \& Wan, 2013). Today, effective pedagogy is very significant in the world of education. It is because, with extensive pedagogical knowledge among teachers, various TL sessions can be implemented to achieve the objectives of TL sessions, especially in terms of context in improving students' understanding. Hence, in facing 21st-century learning, concept of conventional teaching should not be used as the main principle in TL sessions anymore but instead, every teacher should aim to practice various new techniques which can attract students to continue focus during TL sessions without getting tired and bored such as by using ICT in the classroom (Shah, Isa, \& Khadijah 2017).

Malay Literature subject is categorised as an elective subject. Usually, this Malay Literature subject is offered to students who are in the middle class or lower. These students have moderate academic level (Mazlan, 2018). Therefore, several statements indicate that Malay Literature is a bit behind and offers no challenge for those taking this subject. In this regard, to create a better situation in TL of Malay Literature, teachers should not surrender to a couple of common reasons such as students who take Malay Literature do not have other choices which means they are being forced or compelled to take this subject. The other reason is "I take this subject because other elective teachers do not want to accept me". Numerous reasons are being given not only among students but also from administrators, parents and other certain parties. They not only underestimated this subject but also reduced the number of offers for this subject in secondary schools even more. 
INTERNATIONAL JOURNAL OF ACADEMIC RESEARCH IN BUSINESS AND SOCIAL SCIENCES Vol. 10, No. 11, 2020, E-ISSN: 2222-6990 @ 2020 HRMARS

\section{Limitation of Study}

This study is limited to 58 students who take Malay Literature subject. The study is conducted on students who study Malay Literature subject in a selected state, Perak and only three (3) schools to meet the requirements of the study which is ICT applications in TL sessions to generate creative thinking of students in Malay Literature.

\section{Literature Review}

In current development through changes in the latest technological equipment, the majority of society cannot escape from using sophisticated and efficient information and communication technology (ICT) (Joseph \& Wan, 2013). Teachers' job becomes more challenging since every educator is responsible for helping every student to improve their performance in lessons. Therefore, to create effective learning sessions, educators must be smart and creative in choosing and planning TL methods in the classroom. TL sessions which practicing internet communication to play computer applications by exposing literary materials to students in using LCD or ICT. Furthermore, by using the concept of finding information related to the content of literary learning on the internet. Elements that using ICT technology should be implemented appropriately and can attract students to follow it. Good quality teaching methods can help students to follow teaching lessons well and can acquire knowledge related to ICT, skills, cultivate a deep interest in students as well as it also able to help students in terms of understanding in remembering the lessons easily.

Besides, according to Musa (2009), there are numerous definitions of creative thinking such as creative thinking can be defined as the ability to see things from various angles. This style also produces a variety of ways of doing something (Mohd \& Hassan, 1995). Creative thinking is applied to solve problems, create new opportunities and support ideas that are opposite with current thinking. According to Osman (2004), creative thinking can be defined as thinking that is capable of generating new ideas, generating alternatives, seeing things from various angles or perceptions and ability to see things from a broader perspective. Moreover, creative thinking also able to create added value in shaping students' creativity skills. Hence, various efforts have been done to improve the quality of education in various forms of innovation and creativity. In this case, conventional teaching practices through 'chalk and talk' are no longer relevant ( Patdeli, 2018). Students easily feel bored when one-way teaching methods are being practiced by their teachers since teachers do not allow their students to voice out their opinions. Passive teaching without any help in information technology makes students feel bored in the classroom. It happens because few students are too computer literate compared to their teachers so they can also help teachers in the world of ICT.

Furthermore, according to Manjula (2012), the use of ICT in education can provide a space for students to think and communicate creatively and at the same time, it indirectly can help them to succeed in dealing with 21st-century learning. Therefore, teachers should enhance methods, techniques and activities about TL of Malay Literature so that it can be parallel with the world of education today. The use of ICT in teaching and learning sessions (TL) can increase the efficiency and effectiveness of learning outcomes. In this way, teachers can find all the information related to teaching and learning sessions better and also at the end, they can convey to their students effectively. 
INTERNATIONAL JOURNAL OF ACADEMIC RESEARCH IN BUSINESS AND SOCIAL SCIENCES Vol. 10, No. 11, 2020, E-ISSN: 2222-6990 @ 2020 HRMARS

Through the use of ICT as a teaching aid, TL sessions are more interesting and effective (Talirkodi, 2016). For instance, by using tools such as PowerPoint, flash, video, visual and they just need to apply the tools into TL sessions in the classroom. Talirkodi (2016) added that in this way, TL sessions can be carried out more easily, simple and at the same time students are being exposed to interesting descriptions and presentations as well as it becomes easier for them to understand. Hence, students do not easily feel tired and bored during learning sessions because they are attracted to teachers' presentation style by using ICT.

The development of information and communication technology (ICT) has greatly influenced the modern day lifestyle especially in the field of education because applying this technology in TL sessions provides a paradigm shift in teachers' pedagogical techniques (Azhar, 2016). Some past researches have proven that the use of technology has been able to revolutionize the teachers' teaching techniques, learning methods of students and overall way of education being conducted following the current era. As teachers who are facing the information outburst in this borderless world, we need to move forward with progress and sophisticated knowledge as well as technology as a first step to carry the trust and responsibility of the nation in creating a nation that can stand on the world stage.

By mastering the use of ICT, it can help teachers to face all challenges in the world of education and act rightly with the current needs. Teachers are urged to equip themselves with various knowledge, techniques and skills based on information technology to face this challenging world of teaching (Aziz \& Siti, 2007). Functions of teachers as agents of social change can meet the demands of general public through the knowledge and skills that they possess and in the end, they become a reference and idol in the community. Besides, skills of teachers in the field of ICT also can help students to master each skill and knowledge that are appropriate to their interests, talents and potential of students and at the same time can cultivate a love for knowledge. Through this, indirectly it can produce excellent first-class role model as it has been worked out in the "Pelan Induk Pembangunan Pendidikan" (PIPP) (Siti \& Suguneswary, 2016). Eventually, it will be able to produce a generation who are knowledgeable, wise and competitive in realizing it as well as shaping and producing creative-minded students based on advanced information technology.

In that regard, it should be emphasized that the role of ICT applied in the classroom is only as a teaching aid and not to take over all teachers' duties as educators. This application should depend on teaching methods chosen by teachers based on the content of learning to make sure that learning objectives can be achieved by students. Therefore, ICT-based learning needs to be applied wisely by teachers by planning carefully before it is being implemented in the classroom successfully.

In conclusion, 21st-century education focuses on three main components namely technological knowledge, pedagogical knowledge and content or curriculum knowledge. TL in the 21st-century has different characteristics from past education. The objective of 21st-century learning is to produce students who are highly productive, skilled in communication, have high-level thinking skills and skilled in using information and communication technology (ICT). It is because in making sure that teaching objectives can be achieved, teachers need to equip themselves first with various skills before implementing teaching lessons effectively. TL sessions in the 21st-century are based on the 
INTERNATIONAL JOURNAL OF ACADEMIC RESEARCH IN BUSINESS AND SOCIAL SCIENCES

Vol. 10, No. 11, 2020, E-ISSN: 2222-6990 @ 2020 HRMARS

technology used in the teaching sessions to realize the covet of the Ministry of Education (MOE) Malaysia in achieving the level of potential students and IT literate in the world of education which are parallel with 21st-century learning.

\section{Method}

\section{Research Design}

A combination of qualitative and quantitative research methods will be used for this study. Furthermore, field research methods will be used to obtain data. Also, text analysis and literature review will be applied to complete this study. Quantitative data is done by researchers to get a summary of large sources of information and facilitate comparisons in any category in a short time (Kruger 2003). While qualitative data is obtained to strengthen and understand a phenomenon in depth (Merriam, 2002). Therefore, a guide of qualitative data analysis by Othman Lebar (2012) and 4K Integrated Thinking System Theory (SPB4K) generated by Yusof (2010) will be used as a guideline for this study.

\section{Instrument of the Study}

In this study, a questionnaire for students who take Malay Literature subject will be used as an instrument. The questionnaire will be used by researchers to further facilitate the analysis and findings of the study.

\section{Questionnaire}

Questionnaires will be distributed to students who take Malay Literature subject to gather all information from them regarding Malay Literature learning while using ICT approach. Usage of questionnaire can help researchers to get an overall picture related to the characteristics of participants involved in the study based on the background and subjects studied (Robert et al. 2009).

\section{Location of the Study}

Location of the study for collection of qualitative and quantitative research data will involve 3 secondary schools of the Ministry of Education Malaysia (MOE) in the district of Kuala Kangsar. The selection of location for this study is based on the criteria of participants who are selected based on offering the subject of Malay Literature.

\section{Respondents}

The respondents for this study consists of 58 students who take Malay Literature subject and has been chosen in schools at Perak. It involves 15 male students and 43 female students. All respondents have similar backgrounds which students who take Malay Literature subject and all of them are Malay students. Total number of respondents is done based on the needs of researchers in conducting this study.

\section{Results and Discussion}

Based on findings acquired by researchers on the study of ICT applications in TL of Malay Literature to generate students' creative thinking. In the aspect of increasing creative thinking among Malay Literature students, researchers have examined each item and findings obtained from respondents. The answers to every question are illustrated in each table and discussion chart. 
INTERNATIONAL JOURNAL OF ACADEMIC RESEARCH IN BUSINESS AND SOCIAL SCIENCES Vol. 10, No. 11, 2020, E-ISSN: 2222-6990 @ 2020 HRMARS

\section{Section A}

Number of students who take Malay Literature subject

\begin{tabular}{|c|c|c|c|c|c|c|c|c|c|c|c|c|c|c|c|c|}
\hline \multicolumn{4}{|c|}{ Malay } & \multicolumn{4}{|c|}{ Indian } & \multicolumn{4}{c|}{ Chinese } & \multicolumn{4}{c|}{ Others } \\
\hline \multicolumn{2}{|c|}{ Female } & \multicolumn{2}{|c|}{ Male } & \multicolumn{2}{|c|}{ Female } & \multicolumn{2}{|c|}{ Male } & \multicolumn{2}{|c|}{ Female } & \multicolumn{2}{|c|}{ Male } & \multicolumn{3}{|c|}{ Female } & \multicolumn{2}{c|}{ Male } \\
\hline $\mathrm{F}$ & $\%$ & $\mathrm{f}$ & $\%$ & $\mathrm{f}$ & $\%$ & $\mathrm{f}$ & $\%$ & $\mathrm{~F}$ & $\%$ & $\mathrm{f}$ & $\%$ & $\mathrm{f}$ & $\%$ & $\mathrm{f}$ & $\%$ \\
\hline 15 & 26 & 43 & 74 & 0 & 0 & 0 & 0 & 0 & 0 & 0 & 0 & 0 & 0 & 0 & 0 \\
\hline
\end{tabular}

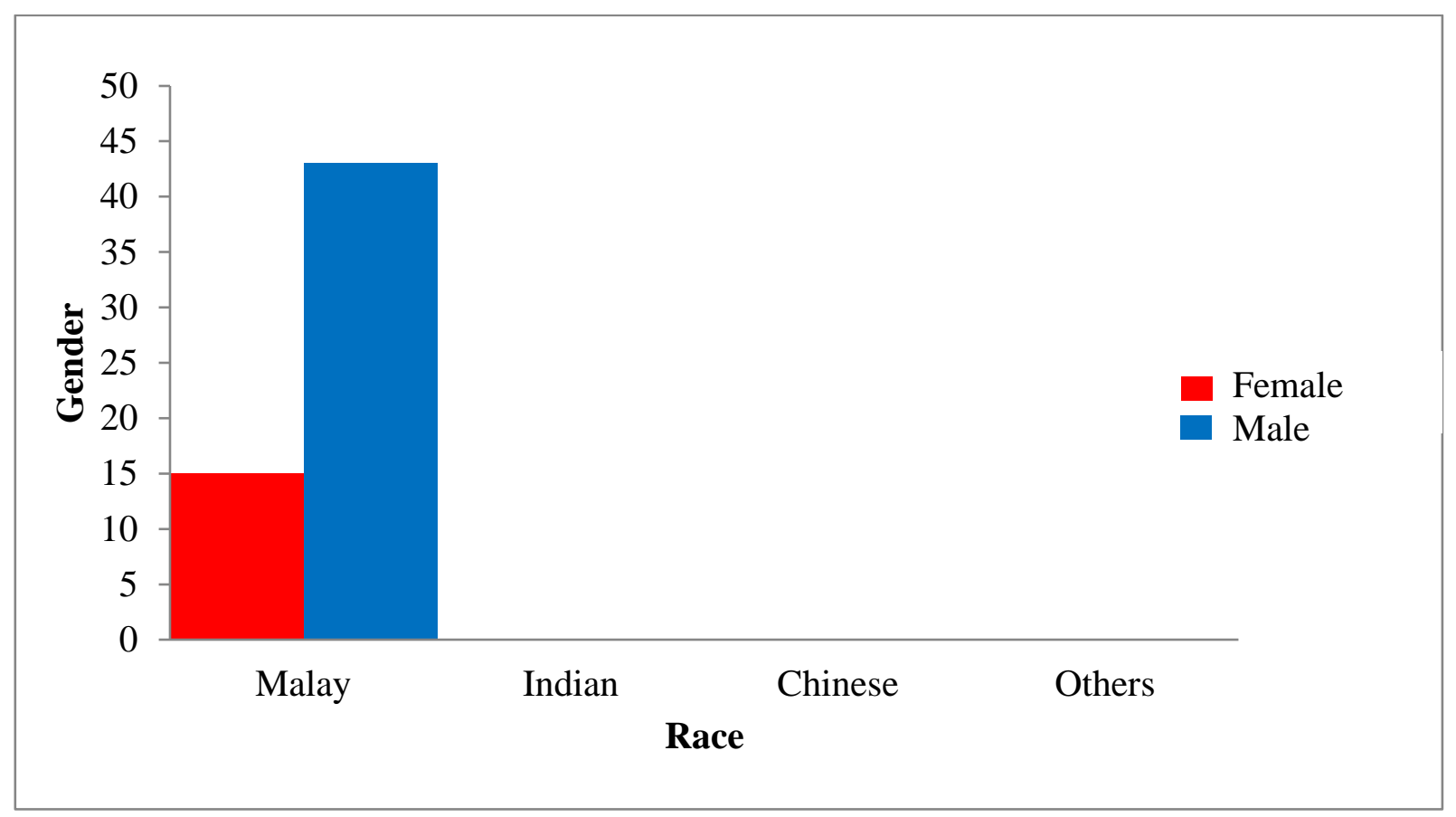

Figure 1: Number and percentage of students from female and male gender which consist of various races.

Based on Figure 1 above, all respondents consist of students who are Malays and it includes 15 of the 58 respondents which are $26 \%$ female students and 43 out of 58 respondents which are $74 \%$ male students among Malay students.

\section{Section B}

Questions related to Malay Literature subject

1. Are you interested in Malay Literature subject?

2. What about teaching methods of literature teachers in the classroom?

3. Do you like teachers who teach the lessons?

4. Do teachers use ICT methods while teaching?

5. Does Malay Literature subject foster a positive attitude in yourself?

6. Do you feel Malay Literature subject is difficult to learn?

7. Do you feel happy to learn Malay Literature subject by using ICT?

8. Do you feel you are increasingly interested in learning Malay Literature subject now? 
INTERNATIONAL JOURNAL OF ACADEMIC RESEARCH IN BUSINESS AND SOCIAL SCIENCES Vol. 10, No. 11, 2020, E-ISSN: 2222-6990 @ 2020 HRMARS

\begin{tabular}{|c|c|c|c|c|}
\hline \multirow[t]{2}{*}{ No. } & \multicolumn{2}{|c|}{ Yes } & \multicolumn{2}{|r|}{ No } \\
\hline & & $\%$ & & $\%$ \\
\hline 1. & 58 & 100 & 0 & 0 \\
\hline 2. & 58 & 100 & 0 & 0 \\
\hline 3. & 58 & 100 & 0 & 0 \\
\hline 4. & 45 & 78 & 13 & 22 \\
\hline 5. & 58 & 100 & 0 & 0 \\
\hline 6. & 23 & 40 & 35 & 60 \\
\hline 7. & 55 & 95 & 3 & 5 \\
\hline 8. & 55 & 95 & 3 & 5 \\
\hline
\end{tabular}

Table 1.1 Views on Malay Literature Subject

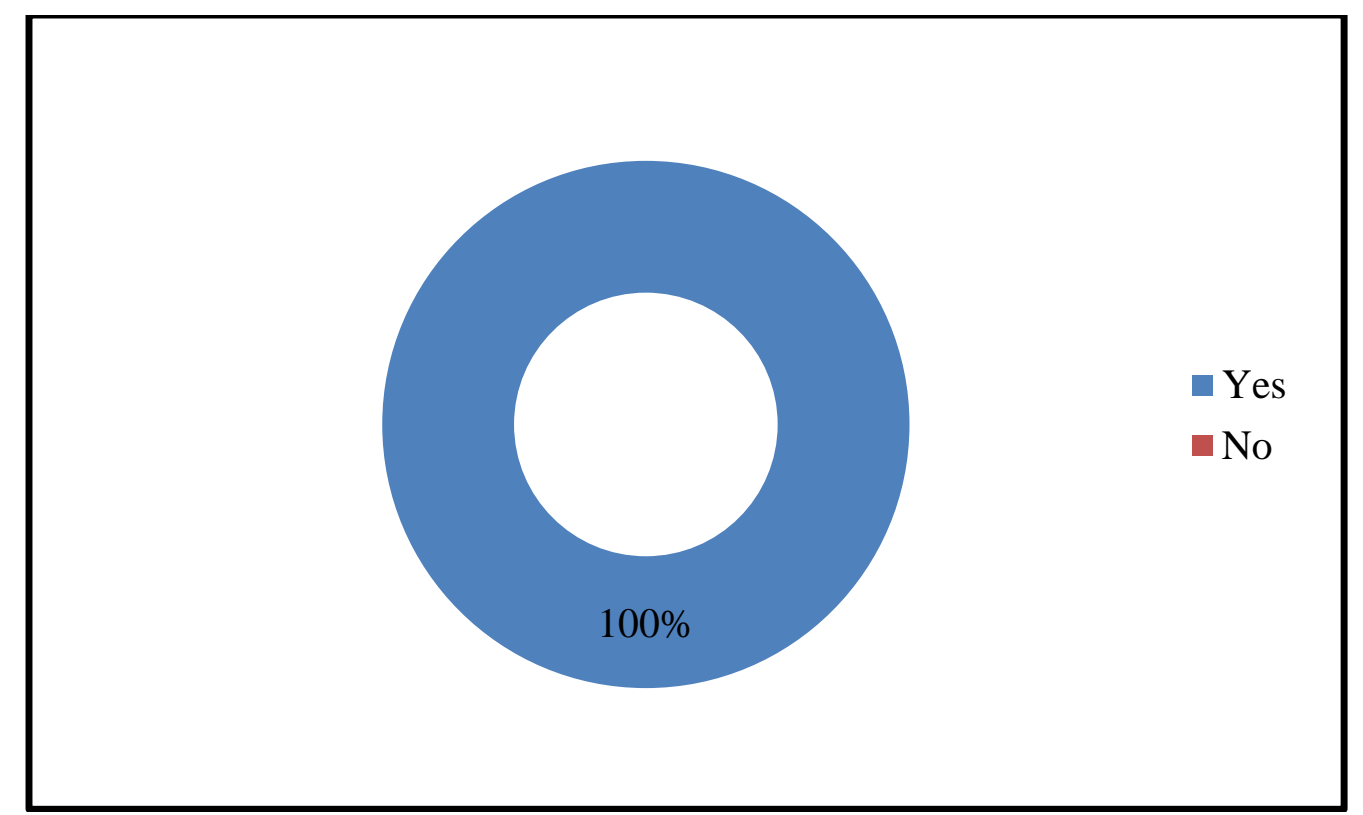

Figure 2: Analysing number of students who are interested in studying Malay Literature subject.

According to figure 2 above, total number of students is 58 out of 58 respondents which is $100 \%$ interested in learning Malay Literature subject. It is because all students consider that Malay Literature subject is a simple subject. Besides, they also consider that Malay Literature subject can educate them on having an interest in reading and learning the concepts of values which needed for them to be practiced in real-life situations through texts obtained from textbooks that have been prepared. Students also can learn this subject very well because their teachers use various interesting teaching and learning methods as well as apply ICT methods and communication approaches in attracting students to learn and interest in Malay Literature subject. 


\section{What about Teaching Methods of Literature Teachers in the Classroom?}

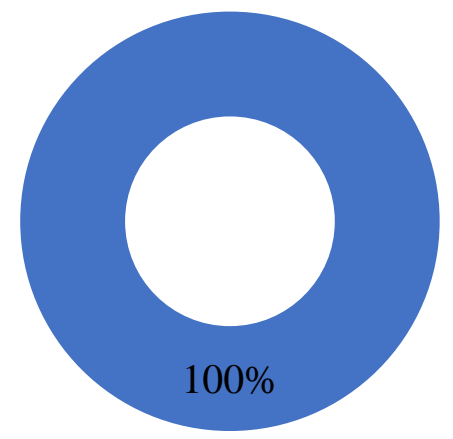

Figure 3: Analysing teaching methods of literature teachers in the classroom

Based on figure 3 above, total number of students is 58 out of 58 respondents which is $100 \%$ agree that teaching methods of literature teachers in the classroom are good. It proves that nowadays, Malay Literature subject teachers are increasingly exposed to TL methods by using information and communication technology (ICT) to assure that TL environment for this subject is more attractive and not boring for their students. In fact, it changes the views of the community and certain parties regarding Malay Literature subject is only a subject that uses traditional teaching methods. Interesting teaching methods of literature teachers in the classroom will attract students' attention to focus more and become more interested in learning Malay Literature subject. In particular, the use of ICT by teachers who teach Malay Literature subject makes this literature parallel with other subjects.

Do you like teachers who teach the lessons?

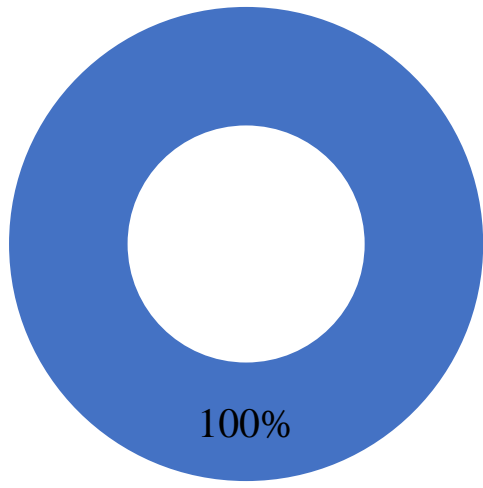

Yes

No

Figure 4: Analysing number of students regarding their liking about teachers who teach the lessons

According to figure 4, total number of students is 58 out of 58 respondents which is $100 \%$ state that they like teachers who teach the lessons. It happens because students may be interested in the ways and methods of teachers who teach them. Therefore, the teaching methods performed by teachers 
INTERNATIONAL JOURNAL OF ACADEMIC RESEARCH IN BUSINESS AND SOCIAL SCIENCES Vol. 10, No. 11, 2020, E-ISSN: 2222-6990 @ 2020 HRMARS

in the classroom for each subject should be planned well to ensure that TL sessions can be conducted smoothly. Methods used by teachers also should be interesting in making sure that students' interest and level of interest towards teachers as well as towards a subject can be done. The level of interest for each student is very important to ensure that Malay Literature subject, for instance, can attract other students' attention to learn and can enhance the performance of subjects as well as students and even the school itself.

\section{Do teachers use ICT methods while teaching?}

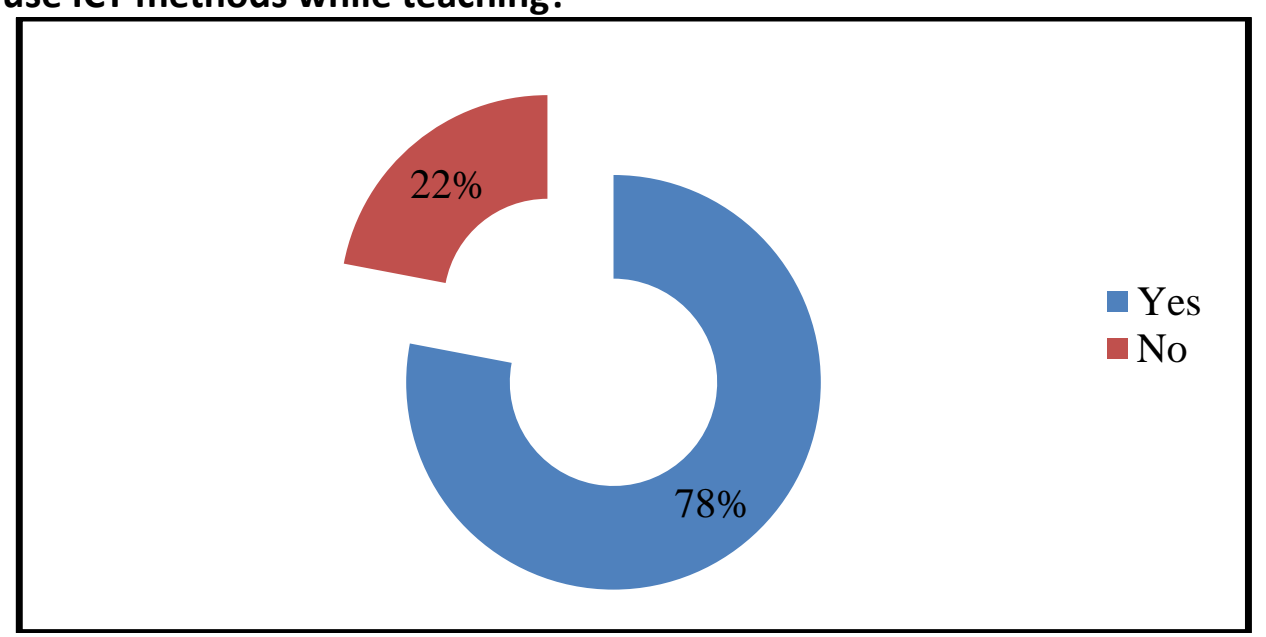

Figure 5: Analysing number of students who use ICT methods while teachers are teaching

Based on figure 5 above, there are 45 out of 58 respondents which is $78 \%$ mention that they use ICT methods while teachers are teaching and only 13 out of 58 respondents which is $22 \%$ mention that they do not use ICT methods while their teachers are teaching. For $78 \%$ of teachers who implement ICT during teaching and learning process in the classroom shows a good effort and should be continued because our education today prioritize on the importance in using ICT skills among teachers and students. The use of ICT methods in the classroom in TL sessions will increase the efforts in educating students on the use of ICT and also will make the atmosphere during teaching and learning process in the classroom more exciting. However, $22 \%$ of students who state that teachers do not use ICT methods during teaching and learning process are probably due to the lack of information and communication technology (ICT) materials required such as LCD, Projector Screen, Computer and others. It may also be due to the teachers who are still not skilled in using ICT methods during TL sessions. 


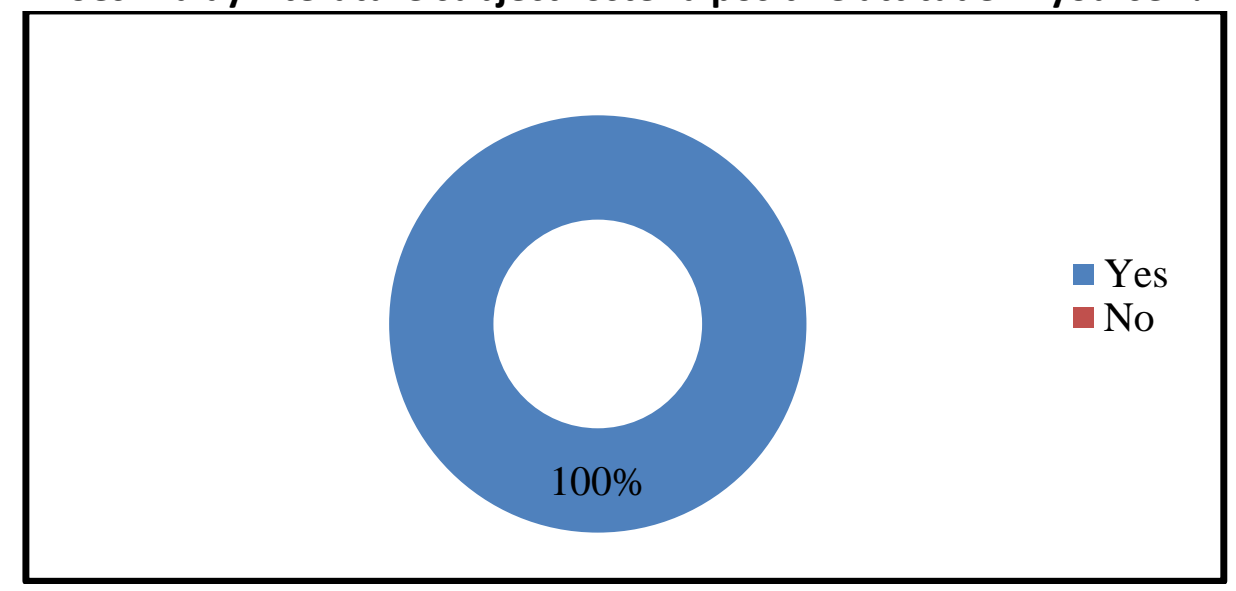

Figure 6: Analysing number of students who feel Malay Language subject can foster a positive attitude in themselves

According to figure 6 above, all students with 58 out of 58 respondents which is $100 \%$ agree that Malay Literature subject can cultivate a positive attitude in themselves. It is common knowledge that Malay Literature subject is filled with elements of values and by teaching this subject, it will be able to educate students about the importance of noble attitudes and good moral values. Besides, this subject is also considered important in educating students to be useful human beings as well as able to educate them to love their country, religion and society. $100 \%$ of students agree that Malay Literature subjects can educate them in fostering a positive attitude in themselves. Syllabus of Malay Literature itself is full of values and lessons that can be practiced by the students themselves. For this subject, each of the works that students studied also cannot be inseparable from applying values and lessons which will nurture students and educate them about positive things that they can practice in their daily lives. In fact, by learning Malay Literature subject, it also can prevent them from getting involved in social ills which are spreading rapidly among teenagers nowadays.

\section{Do you feel Malay Literature subject is difficult to learn?}

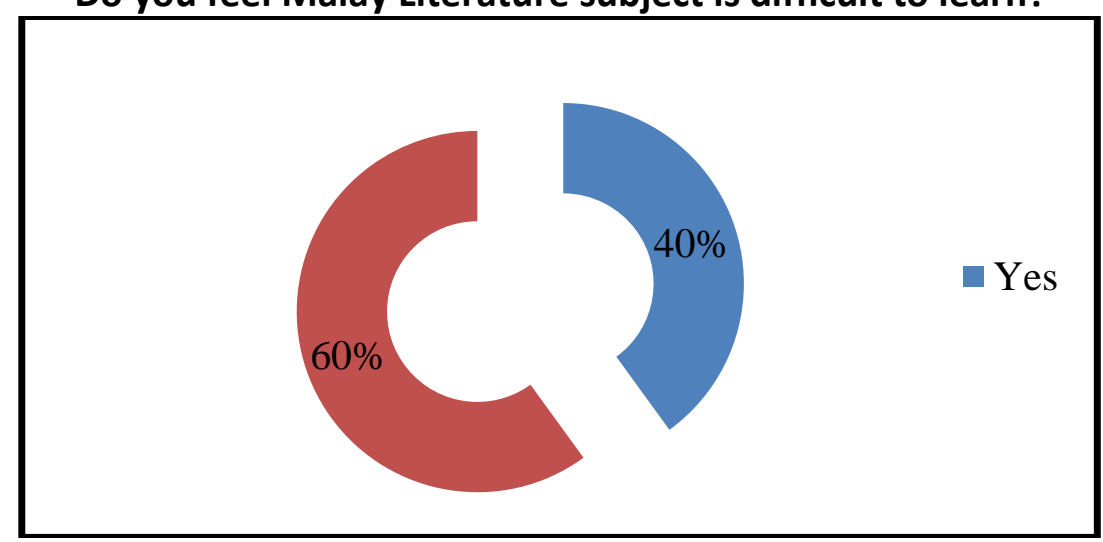

Figure 7: Analysing number of students who feel difficult to learn Malay Literature subject

Based on figure 7 above, there are 23 out of 58 respondents which is $40 \%$ state that they have difficulty in learning Malay Literature subject while only 35 out of 58 students which is $60 \%$ state that they do not have difficulty in learning Malay Literature subject. $40 \%$ of students who are respondents 
INTERNATIONAL JOURNAL OF ACADEMIC RESEARCH IN BUSINESS AND SOCIAL SCIENCES Vol. 10, No. 11, 2020, E-ISSN: 2222-6990 @ 2020 HRMARS

for this study find that Malay Literature is a difficult subject for them to learn. It is because they may feel the amount of texts which they need to learn is too many since they need to grasp all the texts given to them. Moreover, it also requires them to read all the texts and at the same time, they need to master all the texts that they had learned. Other than that, Malay Literature subject also has numerous terms which are quite difficult for them to understand in a short period such as language style, plot, techniques of plot, characters and characteristics even they also need to comprehend the synopsis of each work that they learned. However, $60 \%$ of the students who do not face any difficulties in learning this subject is due to the fact that they can master each syllabus for Malay Literature subject very well. The use of ICT methods in the TL sessions helps in providing some effort to assist $40 \%$ of students who have difficulty in learning Malay Literature subject well.

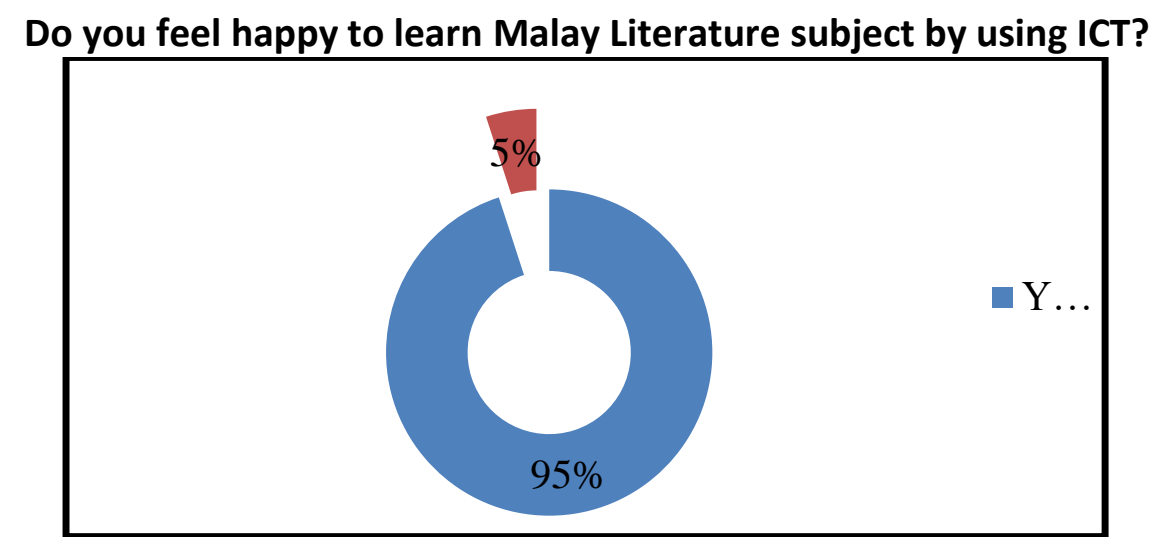

Figure 8: Analysing number of students who feel happy when learning Malay Literature subject while using ICT methods

According to figure 8 above, there are 55 out of 58 respondents which is $95 \%$ say that they feel happy when learning Malay Literature subject while using ICT methods and only 3 out of 58 respondents which is $5 \%$ say that they do not feel happy when learning Malay Literature subject while using ICT methods. 95\% of students who are respondents for this study feel happy when they learn Malay Literature subject because their teachers use ICT methods which able to attract students' attention in following TL sessions that take place in the classroom. There are various methods of using ICT and most of them can be applied by their teachers for TL sessions during Malay Literature subject. Teachers can use numerous ICT methods such as using applications like Kahoot, Powtoon, Tondoo, Quizziz, Classdojo and other applications. Also, teachers can use their innovation and creativity while using ICT methods in the classroom. By using all these methods, it can help students to feel happy and fun throughout TL sessions for Malay Literature subject. But, $5 \%$ of students who do not feel happy during the lessons may be due to they do not like Malay Literature subject and consider this subject is difficult to learn. It can happen because Malay Literature subject is mostly been taught to lower classes. 
Do you feel you are increasingly interested in learning Malay Literature subject now?

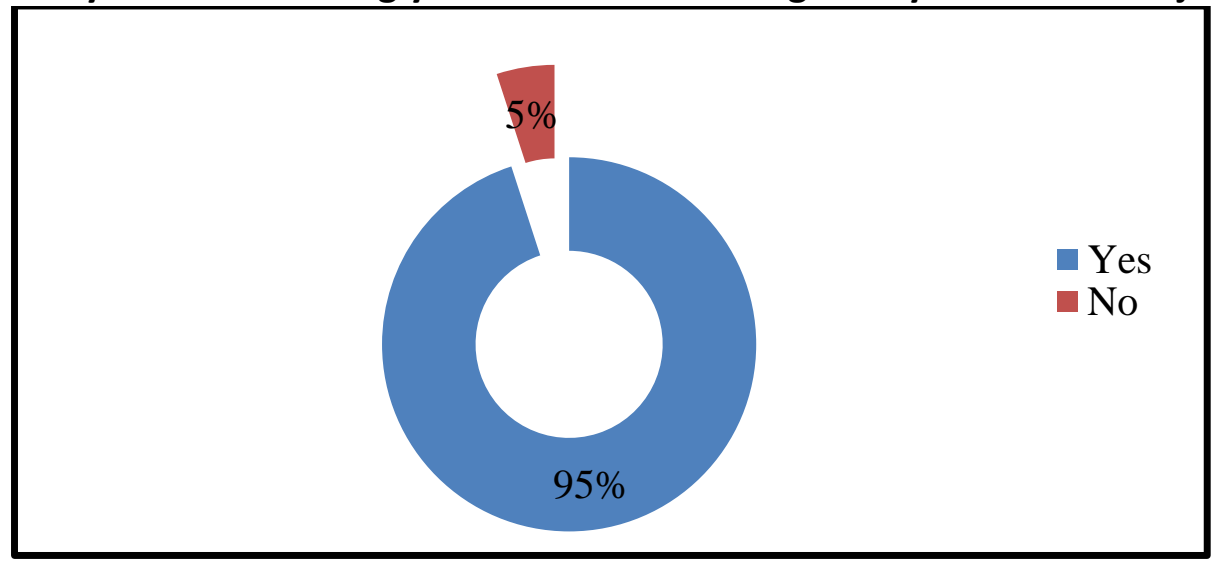

Figure 9: Analysing number of students who feel increasingly interested in learning Malay Literature subject now

According to figure 9 above, there are 55 out of 58 respondents which is $95 \%$ mention that they feel more interested in learning Malay Literature subject now and only 3 out of 58 respondents which is $5 \%$ mention that they are not interested in learning Malay Literature subject now. 95\% of students who are respondents for this study feel that they are more interested in learning Malay Literature subject because their teachers use interesting methods to teach in the classroom. Students feel more interested in learning Malay Literature subject because they think that the usage of ICT methods in the TL sessions in the classroom is an interesting and effective method. In addition, the use of ICT methods in the TL sessions will make the TL atmosphere become more fun and students can think creatively and critically as well as they also will be able to move actively while attending TL sessions in the classroom. The use of ICT methods in TL sessions is one of the methods which able to attract students to be more interested in Malay Literature subject.

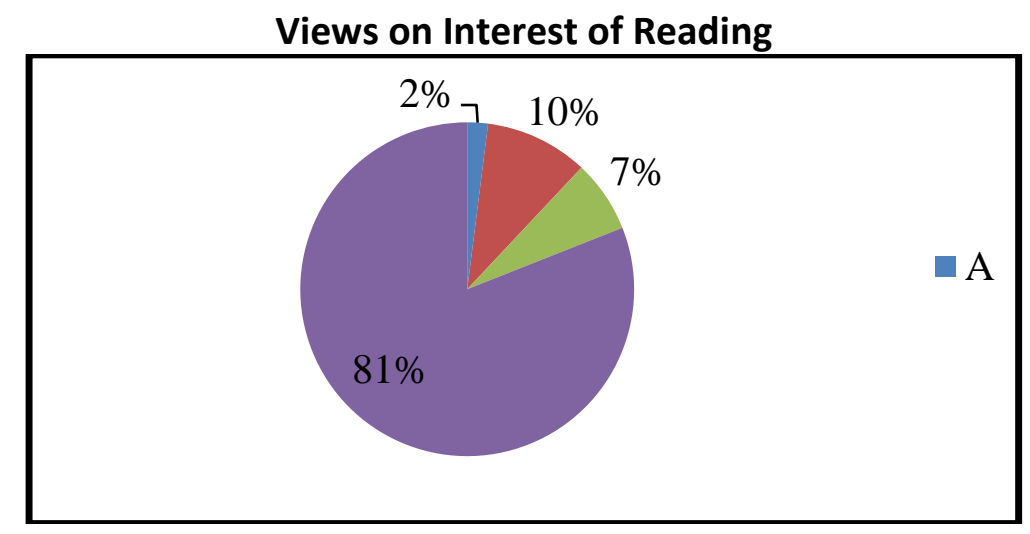

Figure 10: Showing tendency of some students regarding texts which they like to read

Based on figure 10 above, there is only 1 out of 58 respondents which is $2 \%$ choose to answer $A$ which states that they like to read long texts. 6 out of 58 respondents, which is $10 \%$ choose to answer $B$ because they like to read texts in the form of explanations. Apart from that, a total number of 4 out of 58 respondents which is $7 \%$ choose to answer $\mathrm{C}$. It is because they love to read texts that express feelings. In summary, all of the respondents love to read texts in the form of expressing feelings. Texts 
INTERNATIONAL JOURNAL OF ACADEMIC RESEARCH IN BUSINESS AND SOCIAL SCIENCES Vol. 10, No. 11, 2020, E-ISSN: 2222-6990 @ 2020 HRMARS

that convey feelings can help students to appreciate more the texts while reading it and they feel not bored. Besides, texts that involve feelings and manifesting them will touch students' feelings when they read and they will probably have a better understanding regarding the texts that they had read. Students love to play with their feelings and they feel more understand about storytelling through written texts which states about feelings and it will develop empathy within the students.

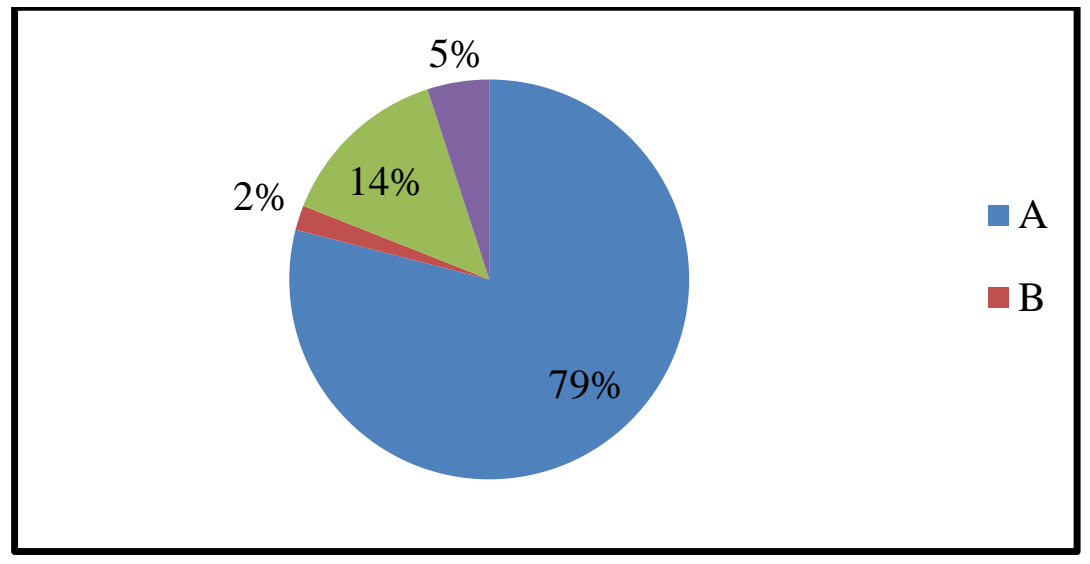

Figure 11: Tendency of students regarding texts which they do not like to read

According to figure 11 above, there are 46 out of 58 students who are respondents for this study which is $79 \%$ of them choose to answer A because they do not like to read texts that are too long. Only 1 out of 58 respondents which is $2 \%$ choose to answer B because they do not like to read texts in the form of explanations. Besides that, a total number of 8 people out of 58 respondents which is $14 \%$ choose to answer $\mathrm{C}$. It is because they do not like to read texts in the form of discussion. Next, a total number of 3 out of 58 respondents which is $5 \%$ choose to answer $D$ because they do not like to read texts that express feelings. In conclusion, respondents do not like to read texts that are too long because long texts have a complicated storyline. Stories that are too long and have too many storytelling plots will cause students to feel bored since they need to read a whole long story to understand the whole long texts. Malay Literature subject has some long texts for example the text from Naratif Ogonshonto novel. The texts are too long and every plot of the story written is difficult to understand which causes students to not like to read especially when they already know the texts are too long.

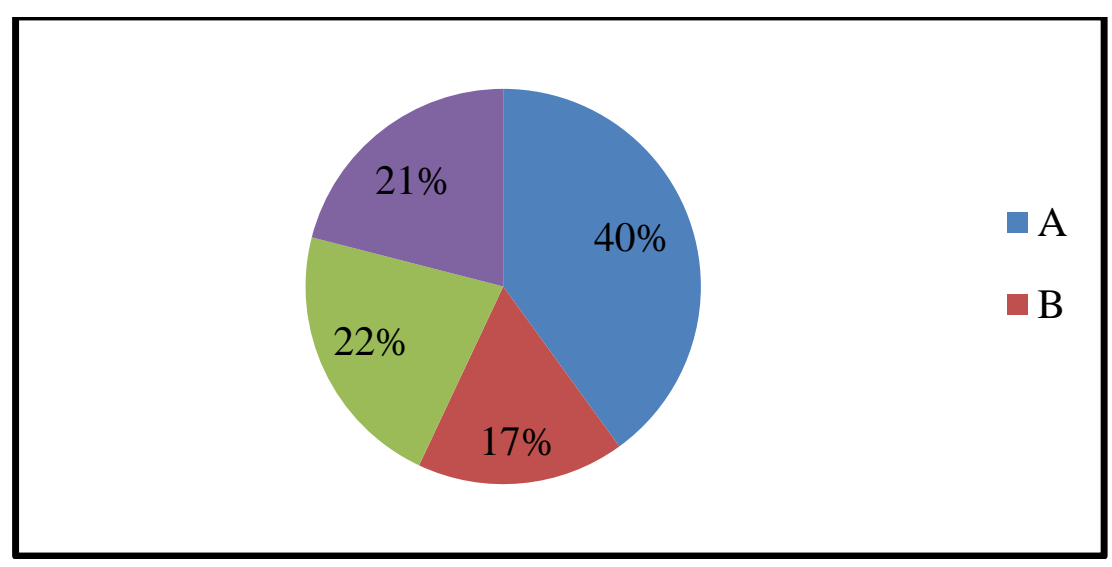

Figure 12: Tendency of students who are interested in reading about any lessons 
INTERNATIONAL JOURNAL OF ACADEMIC RESEARCH IN BUSINESS AND SOCIAL SCIENCES Vol. 10, No. 11, 2020, E-ISSN: 2222-6990 @ 2020 HRMARS

Figure 12 shows that there are 23 people out of 58 respondents which is $40 \%$ choose to answer $\mathrm{A}$. It is because they like to read a particular lesson if it has interesting content. 10 out of 58 respondents which is $17 \%$ choose to answer $B$ because they like to read a lesson if it has a similar situation with their life experience. While a total number of 13 people out of 58 respondents which is $22 \%$ choose to answer $\mathrm{C}$ because they like to read a certain lesson if it suits their interests. Moreover, a total number of 12 out of 58 respondents which is $21 \%$ choose to answer D because they like to read that specified lesson if it can encourage them. In conclusion, overall respondents like to read a lesson if it has interesting content because it helps students to understand the texts regarding what the authors are trying to convey. Texts that have interesting content will not be boring to read, to understand and to learn. Students easily tend to feel bored if they only read texts about facts and uninteresting stories. Hence, interesting text content will help students to enjoy Malay Literature subject because it has a lot of texts that they need to learn. Every content of texts will certainly affect students' interest in every subject.

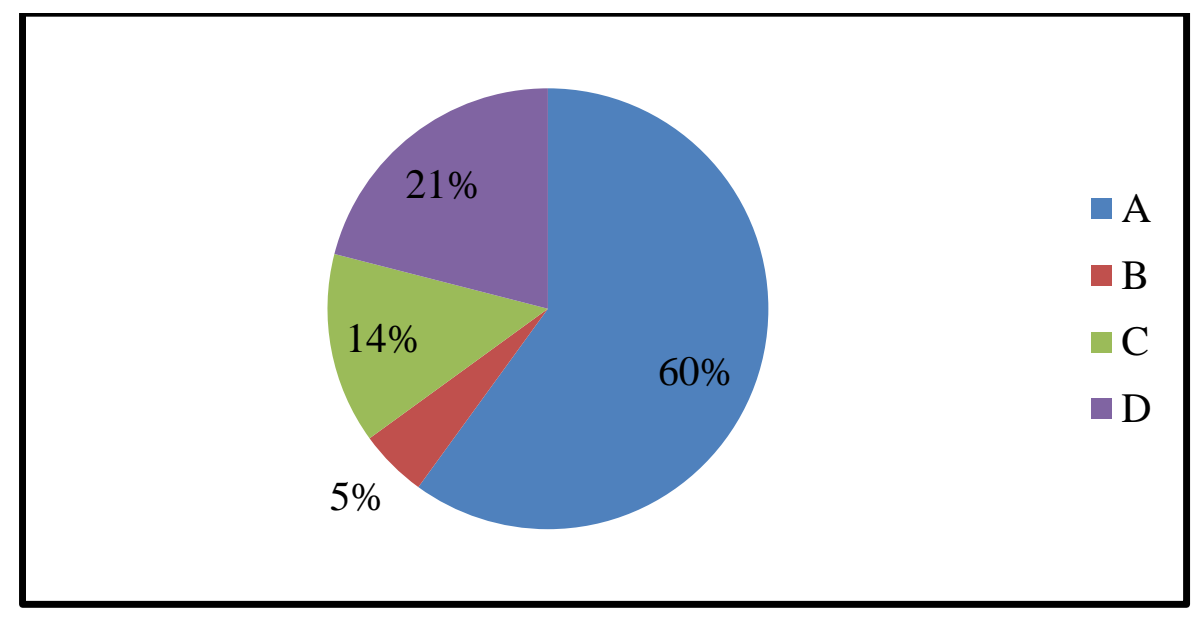

Figure 13: Tendency of students who are not interested in reading about any lessons

Based on figure 13 above, there are 35 out of 58 respondents which is $60 \%$ choose to answer $A$ because they do not like to read specific lesson if it has boring content. A total number of 3 out of 58 respondents which is $5 \%$ choose to answer $B$ because they do not like to read any lesson if it has nothing to do with their life experience. Meanwhile, a total number of 8 people out of 58 respondents which is $14 \%$ choose to answer $\mathrm{C}$ because they do not like to read a particular lesson if it does not suit their interests. Next, a total number of 12 people out of 58 respondents which is $21 \%$ choose to answer $D$ because they do not like to read any lessons if it cannot encourage them. In summary, all respondents do not like to read any lesson if it has boring content. Boring content is not interesting to read and learn. Students will feel distracted by boring text content. However, the use of effective and interesting ICT methods will help students to master any texts which have boring content into interesting texts to learn.

\section{Conclusion}

ICT approach in TL is based on existing researches proves that ICT is a potential tool to help in enhancing students' interest and learning if TL sessions are being planned carefully. According to Rodanny (2016), the application of information technology in TL can develop students' creativity and 
INTERNATIONAL JOURNAL OF ACADEMIC RESEARCH IN BUSINESS AND SOCIAL SCIENCES Vol. 10, No. 11, 2020, E-ISSN: 2222-6990 @ 2020 HRMARS

critical thinking in a learning style that is up-to-date and easy to understand. Reading programs are often seen as a boring program because it only involves books as reading materials and with the motive of reading skills in terms of pronunciation, intonation and comprehension. Hence, ICT is one way that is expected to cultivate students' interest in reading and arouse curiosity. With this, students are encouraged to enhance their reading with the help of ICT usage and at the same time, they can gain knowledge more deeply. Nowadays, the use of ICT in learning process is not a new thing. However, the use of these materials will not be effective if it is not combined with the use of ICT which can lead students towards relevant skills in 21st-century. Moreover, positive effects regarding the use of ICT in learning process are undeniable. Therefore, the use of ICT in learning process is being used in this study with hoping that TL sessions can become more interesting and can instill to students as well as can gain a wider knowledge in mastering about Malay Literature syllabus. It cannot be denied that process of implementing educational transformation requires new approaches and strategies in making sure that students can possess and master every skill needed in the 21st-century (Preliminary Report of Malaysian Education Blueprint 2013 - 2025). To drive the transformation of teaching and learning process that applies usage of ICT, the curriculum is constantly being reviewed, monitored and updated to ensure that it is always relevant with the current needs ( Rahman, Zamri \& Ruzana, 2017). Both teachers and students are not only exposed to literary knowledge but at the same time, current literary and literature information in the latest cyber are also being exposed to them. Besides, they also have the opportunity to work in cyberspace which requires students to be skilled in using multimedia elements in producing a work of cyber literature and students also need to be creative in working at the existing field of literature in cyberspace.

To sum up, results of this study found that the use of ICT in the Malay Literature TL sessions is very effective to enhance creativity skills of Malay Literature students. In addition, it also can help teachers to diversify teaching styles and it will help teachers to assist in conveying accurate and interesting information to students. Furthermore, ICT application in TL sessions also can help teachers to enhance students' performance in conveying information easily and effectively to students. Students who are weak academically especially can increase their interest in following TL sessions as well as improving their academic level to become better. Findings from this study found that most students did not like to read books which are contained in the Anthology textbook even though they had to read manuscripts to get information they had learned. The approach in using ICT needs to be highlighted in making sure that a paradigm shift in changing the pattern of Malay Literature $\mathrm{TL}$ process to be more competitive which can be parallel with the current technology by improving creativity skills of Malay Literature students.

\section{References}

Aziz \& Siti. (2007). Tahap penggunaan teknologi maklumat sebagai pemudah komunikasi dalam proses pengajaran dan pembelajaran (P\&P) dalam kalangan pensyarah politeknik. (Master's thesis). Universiti Tun Hussein Onn, Johor.

Omar, Amir \& Minah. (2019). Confidence and Success of Teachers Integrating ICT in TAF Enhancing Student Interests in Malay Literature. International Journal of Recent Technology and Engineering (IJRTE) Vol-8 Issue-3.

Bester \& Brand, L. (2013). The Effect Of Technology On Learner Attention And Achievement In The Classroom. South African Journal of Education, 33(2), 115. 
INTERNATIONAL JOURNAL OF ACADEMIC RESEARCH IN BUSINESS AND SOCIAL SCIENCES

Vol. 10, No. 11, 2020, E-ISSN: 2222-6990 @ 2020 HRMARS

Chung, Ching, M., \& Jamaludin. (2010). Sikap guru Bahasa Melayu

terhadap penggunaan teknologi maklumat dan komunikasi (ICT) dalam pengajaran di Sekolah-sekolah Rendah di Bintulu, Sarawak. Jurnal Pendidikan Malaysia, 35 (1). pp. 59-65. ISSN 0126-6020 / 2180-0782 Diambil Dari http://journalarticle.ukm.my/143/.

Joseph \& Wan. (2013). Ict Dan Kelestarian Penggunaannya Dalam

Pengajaran Dan Pembelajaran Geografi Di Sekolah. Seminar Pendidikan Sejarah dan Geografi 2013 (UMS, 29 - 30 Ogos 2013. Pusat Pengajian Pendidikan Jarak Jauh Universiti Sains Malaysia Pulau Pinang.

Khairulhasni. (2017). Pembangunan Dan Penilaian Modul Pengajaran Sains (E-Smart)

Berasaskan Pendekatan Konstruktivisme Bagi Menerapkan Kemahiran Berfikir Kreatif Murid Tingkatan 2. Tesis ljazah Doktor Falsafah. Universiti Kebangsaan Malaysia.

Hamzah \& Norazah. (2007). Peranan Pentadbir Dalam

ProsesPerubahan Terancang: Integrasi ICT Dan Pedagogi Dalam Pengajaran Dan Pembelajaran. Journal Quality Monitoring of Strategic Leadership Styles. Jil. 17 Bil. 2. Pahang: Institut Aminuddin Baki.

Yusof \& Zurinah. (2017). Kepentingan Penggunaan Media Sosial

Teknologi Maklumat Dalam Pendidikan Ipta. e-Bangi. Journal of Social Science anad Humanities. Universiti Kebangsaan Malaysia.

Norfarhana. (2012). Tahap Kemahiran Berfikir Kreatif Dan Kritis Dalam Kalangan

Pelajar Diploma Pendidikan Lepasan Ijazah Universiti Tun Hussein Onn Malaysia. Tesis Sarjana Pendidikan Teknik dan Vokasional.

Norasmahani, Aini \& Khadijah. (2015). Impak Teknologi

Maklumat dan Komunikasi (TMK) Dalam Menjana Kemahiran Berfikir Aras Tinggi dalam Pendidikan Islam. Prosiding International Seminar On Tarbiyah (ISOT 2015), HIm 1-14.

Zakaria, Hamzah \& Khadijah. (2017). Penggunaan ICT dalam Pengajaran dan Pembelajaran Pensyarah Pendidikan Islam di Politeknik Zon Selatan. Fakulti Pendidikan Universiti Kebangsaan. Tinta Artikulasi Membina Ummah.

Sharifah \& Kamarul. (2011). Tahap Kesediaan Penggunaan

ICT dalam Pengajaran dan Kesannya Terhadap Hasil Kerja dan Tingkah Laku Murid Prasekolah. Jurnal Pendidikan Malaysia 36(1)(2011): 25-3.

Siti \& Suguneswary. (2016). Penerimaan Guru Terhadap Penggunaan Teknologi Maklumat Dan Komunikasi Berasaskan Model Tam Dalam Pengajaran Mata Pelajaran Bahasa Tamil. Jurnalkurikulum \& Pengajaran Asia Pasifik. Bil. 4, Isu 2. Universiti Malaya.

Talirkodi. (2016). Hubungan Motivasi Guru Dengan Penggunaan Ict Dalam

Pengajaran Di Sjk (T) Daerah Kuala Muda Yan. International Seminar on Generating Knowledge Through Research, UUM-UMSIDA, 25-27 October 2016, Universiti Utara Malaysia, Malaysia.

Thanabalan \& Thanabal. (2015). Persepsi Terhadap Penggunaan ICT dalam Pengajaran Pendidikan Jasmani dan Pendidikan Kesihatan dalam Kalangan Guru PJPK di Kedah. Prosiding Seminar Penyelidikan Pendidikan Kebangsaan (SPPK) 2015. HIm 511- 522.

Zanzali. (2010). Penggunaan Ict Dalam Pengajaran Dan Pembelajaran Matematik Di Kalangan Guru-Guru Pelatih UTM. Fakulti Pendidikan, Universiti Teknologi Malaysia, Johor. 
INTERNATIONAL JOURNAL OF ACADEMIC RESEARCH IN BUSINESS AND SOCIAL SCIENCES Vol. 10, No. 11, 2020, E-ISSN: 2222-6990 @ 2020 HRMARS

\section{Authors' Biodata}

Amir Zahari, is a lecturer of the Department of Languages and Malay Literature, Sultan Idris University, Perak. Holds an undergraduate degree in Creative and Artistic Technology at the University Tecnology Mara (UiTM) Puncak Perdana, specializing in Artistic and Technology Theatre. I pursued Master's in Drama Education at the Cultural Center University of Malaya. He is currently pursuing his Doctor of Philosophy (PhD) degree in Malay Literature (Literature Education). Experienced in 13 years in the performing arts and management part such as directing, assistant director, management, cast and scriptwriter. I have also organized research events for theater in education such as Theater in education (TIE) and drama in education (DIE).Tel no: +60176256214 Email: amir.mz@fbk.upsi.edu.my

\section{Co-authors}

Associate Prof Dr Rohizani is currently working at the School of Education, Universiti Sains Malaysia. Her expertise in the field of pedagogy and curriculum and methods of teaching Malay Literature. Email: Rohizani@usm.my 